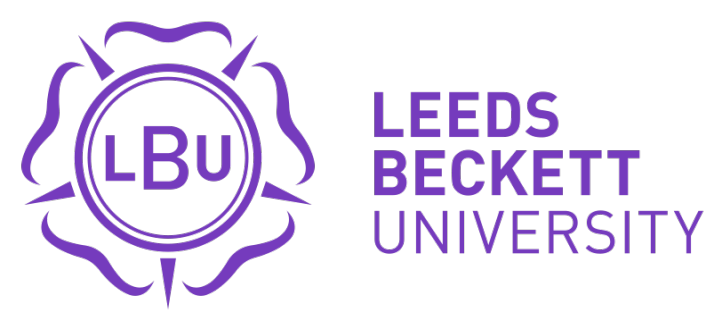

Citation:

Spracklen, K (2016) Theorising northernness and northern culture: the north of England, northern Englishness, and sympathetic magic. Journal for Cultural Research, 20 (1). pp. 4-16. ISSN 1479-7585 DOI: https://doi.org/10.1080/14797585.2015.1134056

Link to Leeds Beckett Repository record:

https://eprints.leedsbeckett.ac.uk/id/eprint/1776/

Document Version:

Article (Updated Version)

The aim of the Leeds Beckett Repository is to provide open access to our research, as required by funder policies and permitted by publishers and copyright law.

The Leeds Beckett repository holds a wide range of publications, each of which has been checked for copyright and the relevant embargo period has been applied by the Research Services team.

We operate on a standard take-down policy. If you are the author or publisher of an output and you would like it removed from the repository, please contact us and we will investigate on a case-by-case basis.

Each thesis in the repository has been cleared where necessary by the author for third party copyright. If you would like a thesis to be removed from the repository or believe there is an issue with copyright, please contact us on openaccess@leedsbeckett.ac.uk and we will investigate on a case-by-case basis. 


\title{
Theorizing Northernness and Northern Culture: The North of England, Northern Englishness, and Sympathetic Magic
}

\begin{abstract}
Northernness is something that is simultaneously as real as the millstone grit of the Pennines, and as inauthentic as the simulacra Roman texts that gave the hills their name. Drawing on the work of Baudrillard, Anderson and Frazer, this paper offers a strong critique of the 'commonsense' idea of northernness expressed in culture by and about the north. The paper begins by attempting to understand this construct historically and from the inside, anthropologically and sociologically. A discussion of the ways in which northernness is claimed to be constructed and performed through shared myths will allow for a wider analysis of how the north is still constructed hegemonically by outsiders: as an essential place of Othering and wilderness. I argue that previous scholarship about northern culture and northern England has also contributed to this essentialism. It will then be shown how northernness has become a form of Frazerian sympathetic magic, performed and invoked to account for cultural practices and beliefs that have been invoked elsewhere for the purposes of hegemonic power.
\end{abstract}

Keywords: Baudrillard, Frazer, Identity, Myth, Northernness 


\section{Introduction}

If there is a sacred omphalos to the north of England, it might be the millstone-grit outcrop on top of the moor on which I am often found: Skipton Moor. This moor is the last point at which the sandstones of millstone grit, which make up the spine of the Pennine hills, are found before being ruptured by the waters of the Aire Gap. Below is the geological fault that brings limestone to the surface, then beyond that are the Yorkshire Dales, a combination of both types of stone, a combination of both types of landscape: the bleached white base of lime, the peat-drenched acid of sand. From where I stand I can see the Brontëan wilderness above Haworth, the radio transmitters (without their hats?) on Ilkley Moor, witch-haunted Pendle Hill and a crowd of peaks in the heart of the Dales: Buckden Fell, Great Whernside, Simon’s Seat. When mist and hard rain hide the view, it still feels to me like an authentic northern place, possibly more so. Rain, brown grass and blackened millstone grit make this place feel truly northern.

In the eighteenth century, an Englishman in Denmark called Charles Bertram discovered a medieval manuscript that supposedly preserved authentic names and details of Roman Britain $^{1}$, and it became a popular source for antiquarians, and later historians looking to discover the origins of place-names and the Roman names of modern English places (see the discussion in Rivet \& Smith, 1979). It was this work that popularised the name of the Pennines. This, according to Bertram, was the name the Romans called the hills of northern England, in honour of their supposed similarity to the Apennines that formed the backbone of Italy (Collins-Elliott, 2014). It was later shown to be a forgery, almost certainly created by Bertram himself (Rivet and Smith, 1979). The received wisdom now is that the name had not been used until Bartram published his supposed discovery, though George Redmonds (2007, pp. 65-68) shows that earlier antiquarians such as Defoe and Camden made similar comparisons between the hills of the northern England and the Apennines. Camden is cited in Redmonds (2007, pp. 67-68) as comparing Yorkshire’s Skipton "hidden and enclosed among steep Hilles to Latium in Italie, which Varro supposeth to have been called because it lyeth close under the Apennine and the Alps”. Redmonds (2007, p. 68) then continues to cite Camden, who says:

the North part... riseth up and swelleth somewhat mountainous, with moores and hilles, but of no bignesse, which beginning here runs like as Apennine doth in Italie, through

\footnotetext{
${ }^{1}$ He published this work, the De Situ Britanniae, first in Latin in 1757, then eventually translated into English: Bertram 1809).
} 
the middest of England... even as far as Scotland, although oftentimes they change their name.

But comparing the hills to the Apennines is not the same as showing they were named after the Apennines before Bertram wrote his forgery. It is quite clear that the Roman (or British) origin of the Pennine name is a romantic delusion. The name of the Pennines however, lives on. It is a fake that has taken on a life of its own, an artifice of northern English roots that lives on in guide books such as the one written by Alfred Wainwright (1968) for the Pennine Way long-distance footpath. And the Pennine Way itself marks out this conceit, legitimating the invention of Bertram with every artificial step cut into the hills.

The artifice of northernness is apparent in the $\mathrm{BBC}$ comedy series The League of Gentlemen (production details and critical discussion in Hunt, 1998). We are invited to view the town of Royston Vasey from the local shop set high on the hills above it. It is raining when we first see the local shop, and the rain follows the camera as it pans across the town's black sandstone terraces. Royston Vasey of course is not real, it is a simulacrum of a northern town under the moors, at the end of the railway line. But it is a real place: the small town of Hadfield on the western edge of the Pennines, close to the borders of the Peak District National Park. Royston Vasey, we are told, is just like Hadfield, and we can walk the streets where the grotesque butcher Hilary Briss sold his "special stuff” to local worthies (Toylan, 2012). The local shop up on the moor, though, is as difficult to find as the meaning of northernness. Its appearance above Roston Vasey is a fake. It does not loom over Hadfield. In fact, the local shop was constructed by the film-makers above a completely different town on the eastern side of the Pennines. If one wishes to find the spot where the fake shop was constructed one can get the GPS details on-line at a fan site and take selfies of oneself at the spot, overlooking the town of Marsden. But there is nothing to see here, no local shop, no material associated with Royston Vasey, just the brown grass and green valley below.

Northernness is something that is simultaneously as real as the millstone grit of the Pennines, and as inauthentic as the simulacra Roman texts that gave the hills their name. Everybody in England knows about northernness (the idea that culture in the north of England is somehow different), and other European northern countries might invoke the notion of northernness to describe otherness and marginality - and yet the computer programme on which I am writing this paper refuses to accept northernness as a real word, underlining it with the disapproving red line of correction. This paper provides a strong critique of the "commonsense" idea of northernness expressed in culture by and about the north. The paper will begin 
by attempting to understand this construct historically and from the inside - as I am a northerner, I draw on my own experience of being northern - anthropologically and sociologically. At this point I will introduce my theoretical framework drawing on the work of Anderson (1983) and Baudrillard (1986, 1988, 1994, 1995). A discussion of the ways in which northernness is claimed to be constructed and performed through shared myths leads to a wider analysis of how the north is still constructed hegemonically (Gramsci, 1971) by outsiders: as an essential place of Othering and wilderness. I argue that previous scholarship about northern culture and northern England has also contributed to this essentialism. I then begin to develop my own theory of northernness by placing this construction within a framework of beliefs constructed by the Victorian folklorist James George Frazer (1922). It will then be shown that northernness has become a form of Frazerian sympathetic magic, performed and invoked to account for cultural practices and beliefs that have been invoked elsewhere for the purposes of hegemonic power.

\section{The North, Northern Britain and Northern England}

People have left traces of their lives in the north for thousands of years. Such traces can be followed in the official Ordnance Survey maps of the localities, whether we think of the north as being the north of the island of Britain, or the north as the north of England. These traces are archaeological sites measured and labelled on the maps in strange fonts, distinguishing Roman ghosts from the ghosts of early farmers, tribal leaders and monks. The traces are also the landscape, its villages and towns, its place-names, folk tales and cultural practices (Ehland, 2007; Kirk, 2000; Russell, 2004). Rugby league, for example is often invoked as a pure example of a leisure activity that defines the north of England, and which is defined by the north. Its supporters think of themselves as being defenders of an authentic, white workingclass culture that has been almost completely destroyed by the ravages of post-industrialisation (Spracklen, Long \& Timmins, 2010). As the sport split away from rugby union in a row over payments to players, and as the game's heartlands were working-class communities in parts of Yorkshire, Lancashire and Cumberland, there is some truth to it being a form of sport based on resistance to the ruling elites (Collins, 1999, 2006). But rugby league's northernness is completely symbolic and imaginary, to the extent that the north in the minds of rugby league fans become synonymous with places where rugby league is played, and places that do not play rugby league are not part of this simulacrum of the north. Rugby league's players and supporters are not hewn from the coal-seams, are not as hard as the millstone grit on the moor 
tops. Rugby league is not a northern game, it is of the north but is allowed to be enjoyed anywhere, by anyone (Spracklen, 2007).

Rugby league's northernness is imposed on it from the outside, by those in the south of England who follow and support rugby union. It is much easier to think of the league version as some kind of aberration of proper rugby played by marginal people who come down to the capital once a year to play at Wembley (Collins, 2006; Russell, 2004; Spracklen, Long \& Timmins, 2010). We do not know what the Catuvellauni or Atrebates thought about the Brigantes, the British people who lived in the hills to the north of their homelands, but we do know what the Romans thought of them and other British people in the north of the island. To the Romans, all of Britain was marginal, a fable island far across the ocean, a source of tin, slaves, dogs (Mattingly, 2008). When the Romans invaded they established themselves in the corner nearest to the mainland, and from here, according to historical sources, the Brigantes and the other northern British tribes were viewed as troublesome neighbours (Hanson \& Campbell, 1986). Rebellions and invasions left their mark on the landscape and on the psyche of the Romans, who left much of northern Britain under military occupation. In the post-Roman age, primary sources are scarce and our knowledge of the north is minimal until Bede writes his narrative of the arrival of the English in his Historia ecclesiastica gentis Anglorum (Bede, 1991). At this time there is no England, but a number of polities that consider themselves to be English, including Northumbria, which extends its power across much of England and Scotland. Northumbria survives as a region for hundreds of years, but its political importance is lost to the kingdoms further south (Fleming, 2011). The establishment of a Viking kingdom at York leaves it mark on accents, dialect and place-names, but the north of England remains a marginal buffer zone between the English and the ancestors of the Scottish. Then another set of conquerors, the Normans, take over England's hegemonic elite, and retain the view that the north of England is a source of rebellion, a place to be held tightly by feudal barons, a place to be turned into hunting forests or donated to religious houses (Daniell, 2013).

The narrative of the Norman yoke on the good folk of the north of England is a popular myth in more recent popular culture. Robin Hood is a folkloric figure who appears first in songs and dances associated with festivals and holy days. By the nineteenth-century Robin Hood has become a Saxon (English) hero fighting to protect his people from the despotic violence of the villainous Normans, exemplified by the Sheriff of Nottingham (Dixon-Kennedy, 2013). In the twentieth-century iterations of the story, Robin's northernness is sometimes lost under the lights of Hollywood, but in Britain, various local history societies, councils and tourist boards claim Robin Hood as an authentic son of Yorkshire, or Nottinghamshire (Ball \& Stobart, 1998). 
In the 1980s television series Robin of Sherwood (production details at: http://www.imdb.com/title/tt0086791/), many of the supporting characters around Robin are played by actors speaking with Yorkshire accents, and there are frequent mentions of real places in the north of England as destinations and origins for various agents. In this version, Guy of Gisburne is played as a nazi officer by a tall man with blond hair and blue eyes; he has a permanent sneer, reminding viewers that the Normans, like the Nazis, belong to Europe and the Saxons are the "real” English. Although the series was filmed on location mainly around Bristol, where the production company was based, some of the most powerful scenes of fighting between Robin and the Normans were filmed at Bamburgh castle, and the beach alongside it, on the Northumberland coast in the north of England.

Nineteenth-century interest in Robin Hood and the struggle between Saxons and Normans occurred as response to, and in shadow of, the growth of industy and the rise of the British Empire. Much of the wealth and resources of the Empire was created in the north of England, where there was a ready supply of hill-streams for water mills, and coal for steam engines. Pit villages, mill towns and industrial cities stuffed with terraced housing became the sites for a construction of a new kind of nothernness, a combination of working-class vigour and capitalist rectitude (Kirk, 2000; Navickas, 2009). The “new men” who founded companies and made their millions from wool or cotton were parodied by the southern and landed elites for their ill manners, their oil-stained fingers and their lack of standing (Russell, 2004). They became figures of fun in literature, strange animals with strange accents and the strange desire to have some political power of their own. At the time the elites of England retreated into classicalism, an imagined community where they could pretend industrialisation had never happened, or they became romantics, fascinated by and reifying the parts of the north of England untouched by industry, or the pre-modern past (Ehland, 2007; Russell, 2004; Spracklen, 2011).

The Romantic view of the north of England was first elaborated by artists and poets such as Wordsworth, who wanted to find a landscape which brought them closer to nature. Others saw the northern landscape as something more pure and wild than the tame farmlands of the south-east of England (Palmer \& Brady, 2007; Wales, 2006). Finding the authentic voice of the northern working-class community became another popular middle-class fashion: who could speak for the north unsullied by the broken world of railways, factories and streets? For most southern, middle-class English people of the period, the novels of the Brontë sisters, Emily’s masterpiece Wuthering Heights especially (published pseudonymously as Bell, 1847), were evidence of an authentic northern voice: wild, remote, parochial, untouched by the 
fashionable flourishes of the capital's jaded writers (Russell, 2004). Wuthering Heights gave the ruling elites in the south a dream-song of wild moors, of people who belong to the moor and people who fear the moor (Heywood, 2001). Elizabeth Gaskell's (1857) The Life of Charlotte Brontë typifies this fashionable re-construction of a supposedly authentic northern culture and landscape to confirm elite prejudices about the north. Reading Gaskell's account of a trip to Haworth one might be fooled into thinking it was at the end of the world, lost in the shadows to the bleak moor, the Parsonage home of the Bronte's on the border between civilisation and barbarity (D’Albertis, 1995). We are encouraged to believe that Emily's genius was a product of the enclosing moors. While Wuthering Heights deserves it continued popularity as a true work of art, the picture it and Gaskell paint of Haworth is ultimately contrived: when modern-day Gaskells arrive at Haworth they find signposts in Japanese and English to help people find their way up to Top Withens, because the moors are actually halfa-mile or more from the main street, beyond a number of fields and a farmhouse. Haworth itself is a respectable suburb of Keighley, with its shops and places of learning, well-placed and central for any middle-class young woman, even in the first half of the nineteenth-century.

At the end of nineteenth-century and into the twentieth century the north of England continued to be source of economic power, and working-class culture became subject to the rational regimes of state controls (Spracklen, 2011). In the north of England the continuing importance of the capitalist classes gave those elites in power the new boroughs as county councils were being established (Wales, 2006). Their tastes in architecture are exemplified by the Gothic fantasies of the town halls that still stand in places such as Bolton, Manchester and Bradford. This civic pride gave the new northern bourgeois classes a taste for sponsoring planned developments such as Saltaire and Port Sunlight, as well as smaller buildings built on philanthropic endeavour: libraries, churches, and later sports clubs. As the counties of Yorkshire and Lancashire saw their urban populations increase, local rivalries emerged over which county was better at making money, and better at cricket (Light 2009). From being an undifferentiated northern England, the county boundaries became markers of cultural difference. The Wars of the Roses were re-told as a struggle between Lancashire and Yorkshire, with each accusing the other of being the source of pomposity, prejudice and ill-manners (Dellheim, 1986; Russell, 2004).

In this period, working-class men and women were encouraged to take part in healthy leisure activities as well as to become consumers of commercial goods (Borsay, 2006; Snape, 2004; Spracklen, 2011). Church groups organised walking and cycling in the moors and hills of northern England as a moral and physical response to the pollution and behaviour of the 
inner cities. But radical left-wing groups did the same, believing that working-class people from the north should be allowed to explore their home country at will. Romantic nationalists believed modernity to be a cruel experiment, and the only authentic way of life was rural, grounded in place and folk traditions (Snape, 2004). This was an age when tour-guides wrote stories about shepherds up in the hills with their (Celtic) British-language number systems, when the north of England's industrial present was whitewashed out of the imagined community, even though the rural landscape beloved of radicals and romantics was itself riven by quarries, lead mines and the waste and desolation of mechanised farming (Rackham, 1990). Working-class walkers began demanding for open access to the moorlands, still owned by feudal landlords and used for upper-class sports such as shooting (Snape, 2004). The growing urban bourgeoisie started to pressure their MPs and the Government to introduce legislation to protect the landscapes of England such as the Yorkshire Dales and the Lake District from urbanisation, pollution and destruction - a pressure that led ultimately to the formation of the National Parks (Rackham, 1990). Walking in the countryside allowed people to literally walk over the north, getting their feet wet in the peat that covers the Pennines, scuffing their knees on the stony ledges in the Lakes. The Pennine Way, mentioned earlier in this paper, became the signifier for the former, a long-distance walk between youth hostels all the way from Edale in Derbyshire to Kirk Yetholm across the Scottish border; for the latter, the signifier was the Alfred Wainwright series of guidebooks, hand-drawn by a local government officer from Lancashire, which affirmed the beatific vision of the Lakes of Wordsworth, while situating such rapture in mundane bourgeois gripes about litter and rowdy sorts (Palmer \& Brady, 2007; Spracklen, 2011).

With the advent of television, the north of England's working-class cultures became commodified, reduced to a simulation of terraced streets, village bobbies, or daft old men. Alan Bennett perfected the notion that there is an authentic northern voice to be found on its everyday streets, engaged in everyday conversations about trivial but important things (Maconie, 2008). Eddie Waring turned the BBC-watching families in the Home Counties into fans of rugby league, with his exclamations (“It's an OOOOp and under!”) and his recitation of exotic names - Wigan, Batley, Hull Kingston Rovers - becoming an easy target of parody for the uppermiddle-class Oxbridge comedy of Monty Python's Flying Circus. Coronation Street taught its viewers to find in the north (or in the Manchester part of it) a source of quiet pride and humour amidst the adversity of being poor, or being a woman in a working-class man's world (Maconie, 2008). Kitchen-sink dramas, in print or in film, attempted to paint more authentic pictures of working-class life. But from Room at the Top to Kes, they told stories that were 
constructed for middle-class tastes and sensibilities (Russell, 2004). There was nothing more pleasing for the southern elites to read a story or watch a film that highlighted the plight of the working classes, the poor who suffered with the rock-steady immobility of moor-top millstone grit, who inevitably suffered for their attempts to break free from the restrictions of northern, working-class life. As the industrial economy shrank under the predations of neo-liberalism, Margaret Thatcher and global capitalism, the north of England's actual communities were traumatised, both the old middle-class managers and shopkeepers, and the working-class families which relied on men’s manual labour in heavy industry (Wainwright, 2010).

In this new century, it seems everybody knows what northern culture is: Newcastle is shiny and tanned but obsessed with football and booze; Liverpool is spikey and maudlin; Manchester has a heart of gold and a cheeky sense of humour to magic away the rain; Yorkshire is cold and full of Geoffrey Boycott clones, an army of complaining, smug men in golfing casual, drinking Yorkshire Tea and counting every penny. The north of England is still seen as a place of mills, mines and factories, or a place of sheep and hills. Every book, television programme or film that uses the north of England as its stage finds in it a world of flat vowels, of menfolk struggling to find a role for themselves while the women make their way in the world proudly. The north is a place where white, working-class masculinity is constructed and performed. The north is still viewed through the lens of the county rivalries, the romantic landscape, the working-class, white, male leisure and cultural habits: eating fish and chips, drinking bitter with a head, listening to brass bands and watching rugby league, as if any of those things are essentially (or inherently) northern, or inherently masculine, or white, or working class (Russell, 2004; Wainwright, 2010). One can find elegies to this white, workingclass north of England in Stuart Maconie's (2008) Pies and Prejudice, which says more about Maconie's own roots - and route to becoming a "professional northerner" in the London media - than it does about authentic northernness. Maconie, of course, is only the latest in a long line of professional northerners - from George Formby onwards through Michael Parkinson to Sarah Lancashire. Actors and other celebrities have found a niche in popular culture through fetishising and celebrating a form of northern culture that is comforting to the audiences and readers, who want everyone to know their place and behave as expected.

Scholars writing about the north have struggled to stand up to this essentialist construction of the north of England. David Russell's book Looking North (Russell, 2004), for instance, is careful to show how much of what he explores as northern culture is the product of a complex struggle between those external to the north and those in the north itself. But he allows the culture of those in the north to carry more authenticity than the cultural texts created 
by outsiders. That is, he allows sports and dialect-writing to be examples of a genuine, industrial working-class Northern culture, which he shows to be marginalised or stereotyped in the travel literature, films and novels of the last two hundred years. This notion that there is some true working-class culture in the North of England is found also in the work of sport historian Tony Collins (1999, 2006), who, as I have already mentioned, has argued that the sport of rugby league defines some essential aspect of working-class culture in the north that has declined or changed in the last thirty years. My own theoretical writing on northernness and leisure (Lucas, Deeks \& Spracklen, 2011; Spracklen, Timmins \& Long, 2010; Spracklen, Lucas \& Deeks, 2014) has drawn on the work of Benedict Anderson (1983) on imagined community. I have argued that northernness is authentic only at the level of the imagined “northernness" is a white, working-class identity constructed from various myths and invented traditions (Hobsbawm \& Ranger, 1983). To be northern in this framework is to put on a Baudrillardian simulacra of the north (Baudrillard, 1994, 1995), a palimpsest on which one writes one's own ideas about what the "true” north is. The north has no essential existence in this framework, because all we can ever know and share are the myths and narratives that allow us to construct and reproduce the simulacrum (Baudrillard, 1988). These myths and narratives are contested by people in the north and people outside the north. They are the subject of hegemonic power relations and others kinds of struggles between elites and marginal communities, between incomers and settled folk, between cities and villages, between men and women, between the marginalised, white working-classes and minority-ethnic groups. In its role as a simulacram northernness serves only to exclude and marginalise people, whether it is the social and cultural exclusion imposed on northerners by those with political power in London, or the cultural barriers imposed by northerners on those that do not fit the stereotype of northernness: those not white, not working class, not hewn from the millstone grit, not born with coal-dust or cotton under their finger-nails. Northernness, I have argued (Spracklen, Lucas \& Deeks, 2014; Spracklen, Timmons \& Long, 2010), is a tool of marginalisation and oppression, a convenient myth that keeps people happy in their subaltern state, because while they might be marginal, they are not as marginalised as those Others who are not allowed to be members of the imagined community. The north is a symbolic wilderness for the hegemonic elites of England. In the days of the Empire, the British ruling classes could look at its "native" subjects in India and Africa with mocking distaste: these foreign Others were wild, un-cultured, the products of the un-temperate weather and harsh landscapes of their homelands (Spracklen, 2013). Now the Empire has gone but the margins of Britain remain as spaces to invoke otherness in wilderness, a landscape where rough people live rough lives, their position in 
capitalism tamed by mocking laughter of the elites at accents and diets. The north of England stands in relation to elite culture and power in exactly the same position as other marginal communities such as the French south: its simulacram is built from myths and stereotypes constructed by the elites to keep the potentially revolutionary, post-industrial working classes in their place (Gramcsi, 1971).

But that is not the full explanation for the survival of the simulacram. Why is the performativity of northernness still acted out if it has been the construct of cultural and political elites in the South? Why do northerners play at being northern, even though the play might exclude others who might have a common political interest in opposing the southern hegemony? To answer that question we need to turn to the idea of sympathetic magic.

\section{Developing a New Theory of Northernness and Northern Culture}

James George Frazer's (1922) The Golden Bough attempts to reveal the secret of the mysterious golden bough, which Aeneas is told by the Sibyl that he has to find and offer to Prosperina if he is to be allowed entry to the underworld. The story is told in the Aeneid, and is presumed to be an invention of Virgil's imagination (Hardie, 2014). For Frazer, the sequence in the Aeneid is an echo of an older mythology of death and resurrection, of sacred kings, sacred trees and a common prehistoric culture to Europe. Frazer's work is incredibly dense, filled with suppositions that become facts before our eyes, facts that are unfairly used out of context, and other wonders of mythological reasoning (Wright, 2014). Anthropologists of the pre-modern or traditional cultures are rightly dismissive of the ways in which he assumed commonalities of structure in culture and history, and historians are dismissive of his inspired, semi-mystical re-telling of paganism (Ackerman, 2013). The Aeneid was of course a popular piece of Victorian classical education, and the painting of The Golden Bough by Turner - who in his landscapes of the north of England established a particularly romantic motif of storms and wet stones - may have been a source of the inspiration for Frazer's re-casting of the story in the sacred grove of Nemi (Wright, 2014). The mise-en-scene at Nemi is painted by Turner in a formal, almost neo-classical style, but he cannot help but bring dark clouds on the horizon. Likewise, Frazer soon moves from the groves of Latinum to the wilds of northern Europe, where barbarian priests burn wicker men filled with human sacrifices. His ideas about death and rebirth hang heavy over neo-paganism and "alternative" popular culture today, directly inspiring the film The Wicker Man (1973, dir. Robin Hardy) (Hutton, 2001; Spracklen \& Spracklen, 2012). 
The accuracy of Frazer's theory of the golden bough and paganism, the development of reason in human societies, and the detail of his grand comparative theory of human religion, are not important here. I am interested in the psychological symbolism at work in the first few chapters of the work (specifically Chapter Three and Chapter Four of the abridged 1922 edition), when Frazer develops a model through which stories become myths about the world, and then taken-for-granted truths. This is his model of what he calls sympathetic magic. How does magic apparently work? Here I have to cite Frazer at length. He (1922, p. 11) writes:

If we analyse the principles of thought on which magic is based, they will probably be found to resolve themselves into two: first, that like produces like, or that an effect resembles its cause; and, second, that things which have once been in contact with each other continue to act on each other at a distance after the physical contact has been severed. The former principle may be called the Law of Similarity, the latter the Law of Contact or Contagion. From the first of these principles, namely the Law of Similarity, the magician infers that he can produce any effect he desires merely by imitating it: from the second he infers that whatever he does to a material object will affect equally the person with whom the object was once in contact, whether it formed part of his body or not... For the same principles which the magician applies in the practice of his art are implicitly believed by him to regulate the operations of inanimate nature; in other words, he tacitly assumes that the Laws of Similarity and Contact are of universal application and are not limited to human actions.

Frazer is trying to understand the reasoning behind the maintenance of magical and religious explanations for things, which are in turn cloaked in cultural practices, especially when the simple epistemological truth is that they have no basis in modern scientific thinking. The sun will not rise if someone is sacrificed, it will rise when it rises because the earth revolves and is in orbit around the sun in such a way that we have the appearance of the sun rising in the eastern part of our horizon every morning (if we live in the north of England, though of course we rarely see the actual sun for the fog, clouds and rain). He is dismissive of such ideas, but of course they were all around him at the time, and continue to be around us today: students still bring their lucky mascots into exam halls; and football players insist on wearing crucifixes which they kiss when they score a goal, as if higher powers have decided to suspend the work of the universe to influence the outcome of a game (Adorno, 2001). His long thought experiment is not based on any research with people living in cultures where magic and religion 
still shape everyday cultural practices, rather he is imagining what might lead people to think that the arrival of spring is brought about through sacrifice. He is trying to build an account of magic and religion that is logically consistent internally - if you believe that there is some sort of power that controls the movement of the sun, and you believe that such power can be transferred to objects and people such as priests, then it becomes perfectly rational to think that some sort of rituals need to occur that persuade or assuage that numinous power. He proceeds to what I believe to be the most important paragraph in the book (Frazer, 1922, p. 59):

The reader may well be tempted to ask, How was it that intelligent men did not sooner detect the fallacy of magic? ... The answer seems to be that the fallacy was far from easy to detect, the failure by no means obvious, since in many, perhaps in most cases, the desired event did actually follow, at a longer or shorter interval, the performance of the rite which was designed to bring it about ... A ceremony intended to make the wind blow or the rain fall, or to work the death of an enemy, will always be followed, sooner or later, by the occurrence it is meant to bring to pass; and primitive man may be excused for regarding the occurrence as a direct result of the ceremony, and the best possible proof of its efficacy. Similarly, rites observed in the morning to help the sun to rise, and in spring to wake the dreaming earth from her winter sleep, will invariably appear to be crowned with success, at least within the temperate zones; for in these regions the sun lights his golden lamp in the east every morning, and year by year the vernal earth decks herself afresh with a rich mantle of green.

The footballer who wears a lucky crucifix knows the crucifix works because wearing it has worked before. The student who takes the mascot into the exam hall knows it might be superstitious but nonetheless knows that to leave the mascot at home would mean a third, or a fail. As Adorno (2001) highlighted, we are all subject to believing in sympathetic magic, despite - and quite probably because of - the Weberian turn in modernity to rationality and disenchantment (Weber, 1992). When our plane is delayed we all curse: just my luck! As we move through the postmodern or liquid world heralded by Baudrillard $(1994,1995)$ and Bauman (2000) we have no choice but to cling onto meaning and the simulation of meaning; because we are bereft of meaning, of power, and of purpose.

Performing identity is one way of following the logic of sympathetic magic. There is an internal logic as to why people choose to adopt the cultural practices associated with an Andersonian imagined community (Anderson, 1983). People know they need do the right 
things to belong: to wear the clothes, talk the slang, listen to the right music, to have the right sort of cultural capital (Bourdieu, 1986). There is no necessary external logic that makes sense to outsiders, which is why such communities often look incomprehensible. Sympathetic magic accounts for the elision from the imagined community to the simulated one found in the hyperreality of Baudrillard (1988, 1995). His America (Baudrillard, 1986) is a country constructed from a combination of myths and symbols that only make sense to those who belong to the hyper-reality of America - stand outside and everything of the simulacram becomes incomprehensible.

So, what is this thing called northernness? What is this realm of popular culture associated with the north of England? There is a hegemonic performativity imposed on the north by people with cultural power in the south of England, people who control policymaking, industries and popular culture. Like Horkheimer and Adorno (1992), we can see the culture industries existing to make working-class culture inauthentic and marginal. The hegemonic centre contrives culture to keep the north of England as dark as colonial depictions of Africa, a dangerous and savage place filled with post-industrial victims: the failed consumers of Bauman's liquid modernity (Bauman, 2000). But northernness is at the same time an identity made by us - by people in the north of England. I am a northerner by birth, by heritage, by choice. I act to preserve my accent even though I am university-educated, I laugh at comedies about "authentic" working-class lives, I get angry when I think about the destruction of the coal mines, I feel at home when I see the Pennines. I read Ted Hughes and think Remains of Elmet (Hughes, 1979) captures some magical truth about the hills, the valleys, the mills and the farms, that supposedly unique cultural geography of the region of the old West Riding. I know and care about the old Ridings of Yorkshire, about rugby league, and proper bitter with a head on it. I perform my own version of northernness even though I consider myself to be suspicious of nationalism, even though I consider myself a cosmopolitan citizen of a globalized world. Northernness is a form of sympathetic magic, which northerners choose to perform, albeit through the constraints of hegemonic cultural formations and the symbolic boundaries and invented traditions of imagined community (Anderson, 1983; Lucas, Deeks \& Spracklen, 2011). So what is that performativity of this sympathetic magic for? Why do northerners perform this northernness that is partly imposed on them?

\section{Conclusions}

In the film The Wicker Man, the sacrificial victim Sergeant Howie is told by the Lord of Summerisle that the crops on the island have failed, and it has become necessary to sacrifice a 
pure man like Howie so that the gods will bring a more verdant harvest the following year. Howie, desperate yet wise, shouts at Summerisle and asks what will happen if the crops fail again, as they surely will. He suggests to Summerisle that if that happens then he, Summerisle, will need to be sacrificed. At this point, Summerisle, played suitably and majestically by Chrisopher Lee, repeats the certainty: they will not fail. The game of sacrifice must be played, the ritual observed with all solemnity and majesty, because it will not fail. Northernness has become the same game for the people who act it out. We become northern, construct this northern performativity, with our imagined community and our invented traditions, because we cannot allow northernness to fail. In our hearts we know that the rituals of northernness have served us well in the past, even if they have been invented for us by the cultural and political elites of the south. Northernness is an invention of ours, but shaped by the constraints that are placed on our agency by the hegemonic cultural elites of the south of England. But we have no choice. We know we must continue to perform, because without the performance of northernness the north of England, the simulation and the imagined community, will collapse. Our northernness is our equivalent of the pagan cycle of the seasons. If we do not perform the rituals of the north, the sun will not rise tomorrow. So we go about our daily business of being northern. Think on, as they say oop north. 


\section{References}

Ackerman, R. (2013). The Myth and Ritual School: J.G. Frazer and the Cambridge Ritualists, Routledge, London.

Adorno, T. (2001). The Stars Down to Earth and Other Essays on the Irrational in Culture, Psychology Press, London.

Anderson, B. (1983). Imagined Communities, Verso, London.

Ball, R., \& Stobart, J. (1998). 'Local Authorities, Tourism and Competition', Local Economy, vol. 12, no. 4, pp. 342-353.

Baudrillard, J. (1986). America, Verso, London..

Baudrillard, J. (1988). Selected Writings, Polity, Cambridge.

Baudrillard, J. (1994). Simulacra and Simulation, University of Michigan Press, Ann Arbor.

Baudrillard, J. (1995). The Gulf War Did Not Take Place, Power Publications, Sydney.

Bauman, Z. (2000). Liquid Modernity, Cambridge, Polity.

Bede (1991). Ecclesiastical History of the English People, translated by Leo Sherley-Price, Penguin, London.

Bell, E. (1847). Wuthering Heights, Thomas Cautley Newby, London.

Bertram, C. (1809). The Description of Britain, Translated from Richard of Cirencester: with the Original Treatise De Situ Britannice; and a Commentary on the Itinerary; Illustrated with Maps, Henry Hatcher, London.

Borsay, P. (2006). A History of Leisure, Palgrave, Basingstoke. 
Bourdieu, P. (1986). Distinction, Routledge, London.

Collins, T. (1999). Rugby’s Greatest Split, Frank Cass, London.

Collins, T. (2006). Rugby League in Twentieth Century Britain, Routledge, London.

Collins-Elliott, S. A. (2014). 'Social Memory and Identity in the Central Apennines under Augustus', Historia, vol. 63, no. 2, pp. 194-213.

D’Albertis, D. (1995). 'Bookmaking out of the Remains of the Dead: Elizabeth Gaskell's The Life of Charlotte Brontë', Victorian Studies, vol. 39, no. 1, pp. 1-31.

Daniell, C. (2013). From Norman Conquest to Magna Carta: England 1066-1215, Routledge, London.

Dellheim, C. (1986). 'Imagining England: Victorian Views of the North', Northern History, vol. 22, no. 1, pp. 216-230.

Dixon-Kennedy, M. (2013). The Robin Hood Handbook: The Outlaw in History, Myth and Legend, The History Press, Stroud.

Ehland, C. (2007). Thinking Northern: Textures of Identity in the North of England, Rodopi, Amsterdam.

Fleming, R. (2011). Britain after Rome: The Fall and the Rise, 400 to 1070, Penguin, London.

Frazer, J. G. (1922). The Golden Bough: A Study in Magic and Religion, Macmillan, London.

Gaskell, E. (1957). The Life of Charlotte Brontë, Smith, Elder and Co, London.

Gramsci, A. (1971). Selections from Prison Notebooks, Lawrence and Wishart, London.

Hanson, W. S., \& Campbell, D. B. (1986). 'The Brigantes: From Clientage to Conquest', Britannia, vol. 17, pp. 73-89. 
Hardie, P. (2014). The Last Trojan Hero: A Cultural History of Virgil's Aeneid, IB Tauris, London.

Heywood, C. (2001). 'Pennine Landscapes in Jane Eyre and Wuthering Heights', Brontë Society Transactions, vol. 26, no. 2, pp. 187-198.

Hobsbawm, E. \& Ranger, T. (1983). The Invention of Tradition, Cambridge University Press, Cambridge.

Horkheimer, M. \& Adorno, T. (1992). Dialectic of Enlightenment, Verso, London.

Hughes, T. (1979). Remains of Elmet, Faber and Faber, London.

Hunt, L. (2008). The League of Gentlemen, Palgrave, Basingstoke.

Hutton, R. (2001). The Triumph of the Moon: A History of Modern Pagan Witchcraft, Oxford University Press, Oxford.

Kirk N. (2000). Northern Identities: Historical Interpretations of the North and Northerness, Ashgate, Aldershot.

Light, R. (2009). 'In a Yorkshire like way: Cricket and the Construction of Regional Identity in Nineteenth-century Yorkshire’, Sport in History, vol. 29, no. 3, pp. 500-518.

Lucas, C., Deeks, M. \& Spracklen, K. (2011). 'Grim Up North: Northern England, Northern Europe and Black Metal', Journal for Cultural Research, vol. 15, no. 3, pp. 279-296.

Maconie, S. (2008). Pies and Prejudice: In Search of the North, Ebury, London.

Mattingly, D. (2008). An Imperial Possession: Britain in the Roman Empire, 54 BC-AD 409, Penguin, London. 
Navickas, K. (2009). 'Moors, Fields, and Popular Protest in South Lancashire and the West Riding of Yorkshire, 1800-1848', Northern History, vol. 46, no. 1, pp. 93-111.

Palmer, C. \& Brady, E. (2007). 'Landscape and Value in the Work of Alfred Wainwright (1907-1991)', Landscape Research, vol. 32, no. 4, pp. 397-421.

Rackham, O. (1990). Trees and Woodlands in the British Landscape. The Complete History of Britain's Trees, Woods and Hedgerows, London, Phoenix.

Redmonds, G. (2007). Names and History: People, Places and Things, Hambledon, London.

Rivet, A. L. F. \& Smith, C. (1979). The Place-Names of Roman Britain, Batsford, London.

Russell, D. (2004). Looking North: Northern England and the National Imagination, Manchester University Press, Manchester.

Snape, R. (2004). 'The Co-operative Holidays Association and the Cultural Formation of Countryside Leisure Practice’, Leisure Studies, vol. 23, no. 2, pp. 143-158.

Spracklen, K. (2007). 'Negotiations of Belonging: Habermasian Stories of Minority Ethnic Rugby League Players in London and the South of England', World Leisure Journal, vol. 49, no. 4, pp. 216-226.

Spracklen, K. (2011). Constructing Leisure: Historical and Philosophical Debates, Palgrave Macmillan, Basingstoke.

Spracklen, K. (2013). Whiteness and Leisure, Palgrave Macmillan, Basingstoke.

Spracklen, K., Lucas, C. \& Deeks, M. (2014). 'The Construction of Heavy Metal Identity through Heritage Narratives: A Case Study of Extreme Metal Bands in the North of England', Popular Music and Society, vol. 37, no. 1, pp. 48-64. 
Spracklen, K. \& Spracklen, B. (2012). 'Pagans and Satan and Goths, Oh My: Dark Leisure as Communicative Agency and Communal Identity on the Fringes of the Modern Goth Scene'. World Leisure Journal, vol. 54, no. 4, pp. 350-362.

Spracklen, K. Timmins, S. \& Long, J. (2010). 'Ethnographies of the Imagined, the Imaginary, and the Critically Real: Blackness, Whiteness, the North of England and Rugby League', Leisure Studies, vol. 29, no. 4, pp. 397-414.

Toylan, G. (2012). 'The League of Gentlemen and 1990s England: Conflicts and Complexities in Sexuality and Gender at the Turn of the Century. Comedy Studies, vol. 3, no. 1, pp. 41-51.

Wainwright, A. (1968). Pennine Way Companion, Westmorland Gazette, Kendal.

Wainwright, M. (2010). True North, Guardian Books, London.

Wales, K. (2006). Northern English: A cultural and social history, Cambridge University Press, Cambridge.

Weber, M. (1992). Economy and Society, University of California Press, Sacramento.

Wright, J. (2014). 'Reflections in Diana’s Mirror: Sir James Frazer’s “Survivals” and the Literary Construction of Nemi', The Victorian, vol. 2, no. 1, pp. 1-15. 